\title{
Performance appraisal of Indian state police forces using ARAS method
}

\author{
Debapriyo Paul, Puneet Kumar Agarwal and Shankar Chakraborty*
}

Department of Production Engineering, Jadavpur University, Kolkata - 700 032, India

\begin{tabular}{l}
\hline C H R O N I C L E \\
\hline Article history: \\
Received October 28, 2015 \\
Received in revised format \\
November 28, 2015 \\
Accepted March 10, 2016 \\
Available online \\
March 14, 2016 \\
\hline Keywords: \\
Police performance \\
MCDM \\
ARAS \\
States/UTS \\
India
\end{tabular}
\begin{abstract}
A B S T R A C T
In the light of recent excess of reported crimes in various states and union territories (UTs) of India, it becomes imperative to evaluate the police performance of different states/UTs in order to identify the poor/under-performing ones requiring immediate attention. Although, a limited amount of research work has been carried out in this area, mainly employing data envelopment analysis approach, a definitive ranking of Indian states/UTs with respect to their police performance has never been derived using any of the multi-criteria decision making (MCDM) techniques. Thus, the aim of this paper is focused on evaluating and ranking of all the Indian states/UTs with respect to their performance in minimizing criminal activities while employing additive ratio assessment (ARAS) method as a simplistic MCDM tool. It is revealed that Chandigarh evolves out as the best performer amongst all the 35 Indian states/UTs, while West Bengal comes out as the worst performer. A detailed analysis of the results is also carried out to identify those Indian states/UTs where substantial improvement can be brought in.
\end{abstract}

\section{Introduction}

Performance measurement is a term that is ubiquitous, present in corporate boardrooms, schools, industrial shop-floors, hospitals and offices. With performance measurement and appraisal appearing in such a diverse array of organizational settings, it is not surprising that it is now becoming a widespread topic in the social spectrum, especially in policing. The police, as we know, act as the protectors of society, and the enforcers of law and order in the community. In India, the police force was originally created out of the colonial interests. India was under the British Rule, when in 1861, the Indian Police Act was enacted. After a long period of 154 years of its journey, the Indian police are still struggling to come out of their colonial image. Unfortunately, there is no national police force in India. The constitution establishes the individual state governments as the superintendent over state police forces. The head of the police force in a state is the Director General of Police (DGP), who is responsible to the state government for administration of the police force in the state and for advising

* Corresponding author.

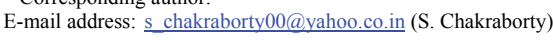


the government on police. Thus, it is quite obvious that the police performance will greatly vary from state to state. Although the police are tasked with battling India's most pressing problems, including armed militancy, terrorism and organized crime, a lack of political commitment and investment by the states has left the police overstretched and ill-equipped. There is just one civil police officer for every 1,037 Indian residents, far below Asia's regional average of one police officer for 558 people and the global average of 333 people. As on $1^{\text {st }}$ January, 2013, there were 130 police personnel for every 100,000 Indian citizens. In states, like Uttar Pradesh and Bihar, which have traditionally had greater law and order issues, the ratio dips to about $65-75$ police personnel per 100,000 citizens, whereas, the global norms laid down by the United Nations (UN) dictate that a minimum of 220 police personnel must be present per 100,000 citizens. The growing insecurity and rise in violent crimes, especially in notorious states, like Uttar Pradesh and Bihar where lawlessness is common, are always the raising questions about police competency in different Indian states. In order to understand the situation in every individual state/UT so that proper corrective measures can be employed, this paper concentrates on determining the ranking of all the 35 Indian states/UTs while implementing a simple multi-criteria decision making (MCDM) tool. Although data envelopment analysis (DEA) was specifically employed by the earlier researchers for evaluating the police performance, a comprehensive ranking of Indian states/UTs has never been obtained which represents a huge research gap in this domain. Studies related to the field of policing try to determine and pinpoint the exact difficulties so that necessary steps for correction can be implemented immediately. The methods and data used to measure police performance at different levels may vary significantly. Since not one, but rather, a multitude of factors is essential for judging police performance. Keeping this in mind, a suitable set of evaluation criteria requires to be chosen. As an appropriate MCDM tool, additive ratio assessment (ARAS) method is employed here to compute the performance indices and rank 35 Indian states/UTs for the purpose of facilitating the police performance appraisal process of Indian administrative zones.

\section{Literature review}

Diez-Ticio and Mancebon (2002) analyzed the efficiency of the Spanish police service applying DEA method while taking into consideration the police activities related to solving of crimes. Sun (2002) employed DEA method to measure the relative efficiency of 14 police precincts in Taipei city, Taiwan. It was concluded that differences in operating environments, such as resident population and location factors, would not influence upon the efficiency of police precincts. Drake and Simper (2003) applied an innovative distance function strategy in contrast to the conventional efficiency techniques in order to assess police force efficiency during the sample period 1996-1999. Moore and Braga (2003) presented an exploratory qualitative analysis of the mechanisms at work in the New York Police Department's Compstat and its application in six other police departments. Drake and Simper (2005) presented a critique on the performance of radar technique proposed by the Home Office in the United Kingdom as a new public policy objective to assess police force performance. Verma and Gavirneni (2006) applied DEA technique for measuring police efficiency. It would help in generating targets of performance, optimal levels of operations, role models that inefficient departments could emulate and the extent to which improvements could be made over a period of time. García-Sánchez (2007) evaluated the level of effectiveness of the National Police Force in Spain using DEA technique. A twostage procedure using econometric methods was implemented to estimate the set of variables which would explain the performance of effective units. Gorman and Ruggiero (2008) evaluated the efficiency of state police services in the continental United States using a multi-stage DEA model. It was observed that most of the states were technically efficient, but nearly half were operating at less than optimal scale size. Sadi-Nezhad and Damghani (2010) applied technique for order preference by similarity to ideal solution (TOPSIS) based on preference ratio and an efficient fuzzy distance measurement model in assessing the performance of traffic police centers. Wu et al. (2010) employed DEA technique to propose a scalar measure of efficiency for all police precincts. Most of the decision making units (DMU) were found to be technically efficient and the average technical efficiency of all DMUs was as high as $98.46 \%$ while taking the external environmental factors into consideration. From a brief review 
of the past literature, it can be easily inferred that DEA method is indeed the most popular choice as an MCDM tool for the purpose of police performance evaluation. However, it cannot be denied that DEA technique suffers from certain disadvantages. The mathematical models required for its implementation are quite difficult to comprehend and further, the complete ranking preorder of the selected alternatives cannot be obtained while employing this method. It only shortlists the efficient DMUs for a specific problem. Additionally, the results derived using DEA method may not be satisfactory while measuring police performance, since crime locations on which DEA method is applied are heterogeneous in context of crime density, area and size of the individual state, thereby making it impossible for the DMUs from two different zones to act as benchmark for one another in DEA model. Since obtaining a definitive ranking of the states/UTs of India is the main objective of this paper, an attempt is thus made to employ a simplistic MCDM technique in the form of ARAS method to appraise the police performance of all the 35 Indian states/UTs. This method employs the concept of degree of optimality for selecting the best alternative amongst a pool of available options while calculating the ratio of the sum of normalized and weighted criteria scores to the sum of the normalized and weighted criteria values (Zavadskas \& Turskis, 2010). Its profound mathematical logic and simple computational procedures prove its successful application in various domains in order to obtain complete ranking of the chosen alternatives (Turskis \& Zavadskas, 2010; Zavadskas et al., 2010; Kutut et al., 2013; Stanujkic et al., 2013).

\section{ARAS method}

A typical MCDM problem is concerned with the task of ranking a finite number of decision alternatives, each of which is explicitly described in terms of different decision criteria which are to be taken into account simultaneously. In this paper, ARAS method is applied for performance evaluation of Indian police forces. According to ARAS method, a utility function determining the complex relative efficiency of a feasible alternative is directly proportional to the relative effect of values and weights of the main criteria considered in a problem. The procedural steps of this method are detailed out herein-under.

Step 1: At first, the related decision/evaluation matrix is formulated. In any MCDM problem (discrete optimization problem), the relevant data is represented by the decision matrix showing preferences for $m$ feasible alternatives rated on $n$ criteria (attributes).

$$
X=\left[\begin{array}{ccccc}
x_{11} & x_{12} & \ldots & \ldots & x_{1 n} \\
x_{21} & x_{22} & \ldots & \ldots & x_{2 n} \\
\ldots & \ldots & \ldots & \ldots & \ldots \\
\ldots & \ldots & \ldots & \ldots & \ldots \\
x_{m 1} & x_{m 2} & \ldots & \ldots & x_{m n}
\end{array}\right]
$$

where $m$ is the number of alternatives, $n$ is the number of criteria describing each alternative and $x_{i j}$ is the value representing the performance of $i^{\text {th }}$ alternative with respect to $j^{\text {th }}$ criterion.

Step 2: Determine the optimal value of each criterion. Let $x_{0 j}$ be the optimal value of $j^{\text {th }}$ criterion. If the optimal value of $j^{\text {th }}$ criterion is known, then

$$
\begin{aligned}
& x_{0 j}=\operatorname{Max}_{i} x_{i j}, \quad \text { for beneficial criterion } \\
& x_{0 j}=\operatorname{Min}_{i} x_{i j}, \quad \text { for non }- \text { beneficial criterion }
\end{aligned}
$$

Now, taking into account the optimal values of all the considered criteria, the original decision matrix is reformulated as follows: 


$$
X=\left[\begin{array}{ccccc}
x_{01} & \ldots & x_{0 j} & \ldots & x_{0 n} \\
\ldots & \ldots & \ldots & \ldots & \ldots \\
x_{i 1} & \ldots & x_{i j} & \ldots & x_{i n} \\
\ldots & \ldots & \ldots & \ldots & \ldots \\
x_{m 1} & \ldots & x_{m j} & \ldots & x_{m n}
\end{array}\right]
$$

Step 3: In this step, all the initial criteria values are normalized while employing the following equations.

For beneficial criteria,

$$
\bar{x}_{i j}=\frac{x_{i j}}{\sum_{i=0}^{m} x_{i j}}
$$

For non-beneficial criteria,

$$
x_{i j}^{*}=\frac{1}{x_{i j}}, \bar{x}_{i j}=\frac{x_{i j}^{*}}{\sum_{i=0}^{m} x_{i j}^{*}}
$$

Step 4: From the normalized decision matrix, the corresponding weighted normalized decision matrix is developed using the following equation:

$$
\hat{x}_{i j}=\bar{x}_{i j} \times w_{j}, \quad i=0,1,2, \ldots, m
$$

where $w_{j}$ is the weight of $j^{t h}$ criterion and $\bar{x}_{i j}$ is the normalized performance of $i^{\text {th }}$ alternative with respect to $j^{\text {th }}$ criterion.

Step 5: In this stage, the optimality function value is determined.

$$
S_{i}=\sum_{j=1}^{n} \hat{x}_{i j}, \quad i=0,1,2, \ldots, m
$$

where $S_{i}$ is the value of optimality function for $i^{t h}$ alternative. The highest value of $S_{i}$ always signifies the best alternative, whereas, the lowest $S_{i}$ value identifies the least preferred alternative. Taking into account the computational process of ARAS method, it can be revealed that the optimality function $S_{i}$ has a direct and proportional relationship with $x_{i j}$ values and weights $w_{j}$ of the considered criteria and their relative influence on the final result. The priorities of the alternatives can thus be determined based on $S_{i}$ values. Consequently, it is convenient to evaluate and rank the decision alternatives using $S_{i}$ values.

Step 6: The degree of alternative utility is determined by comparing with a variant, which is often taken as the ideally best value $\left(S_{0}\right)$. The utility degree $K_{i}$ of $i^{\text {th }}$ alternative can be calculated employing the following equation:

$$
K_{i}=S_{i} / S_{0}, \quad i=1,2, \ldots, m
$$

It is quite obvious that the calculated values of $K_{i}$ lie in the interval of $[0,1]$ and can be ordered in an increasing sequence to provide a complete ranking of the considered alternatives. The complex relative efficiency of the feasible alternatives can also be determined according to the utility function values. 


\section{Performance appraisal of police forces in India}

The evaluation of police performance in itself is a very sensitive process which involves a wide range of conflicting criteria. Performance appraisal in the Indian police has largely limited itself to the evaluation of individual officers in the form of annual reports. The performance of a police organization and its units, police stations, districts, and the state police is usually judged either with respect to isolated incidents of crime or public disorder or on the basis of crime, arrest, prosecution and conviction rates. However, crime data alone is not a reliable measure since not all crimes are reported to the police, largely due to mistrust in the organization (Verma \& Gavirneni, 2006). In the earlier research works, numerous criteria, like total expenditure, number of police officers, number of persons convicted in a crime etc. have been taken into consideration for police performance appraisal. In this paper, the aspects of heterogeneous nature of state police present in India are not considered, since some states have larger area and population as compared to others, which may lead to an erroneous evaluation. This paper aims to overcome this drawback while incorporating the necessary parameters, thereby drawing attention to a large number of dimensions along which police performance can be assessed. The performance appraisal of state police forces in India is carried out based on seven evaluation criteria, as enlisted in Table 1. All these seven criteria are so selected that they are entirely uncorrelated. Fig. 1 shows the classification of those criteria into beneficial (higher the better type) and non-beneficial (lower the better type) groups.

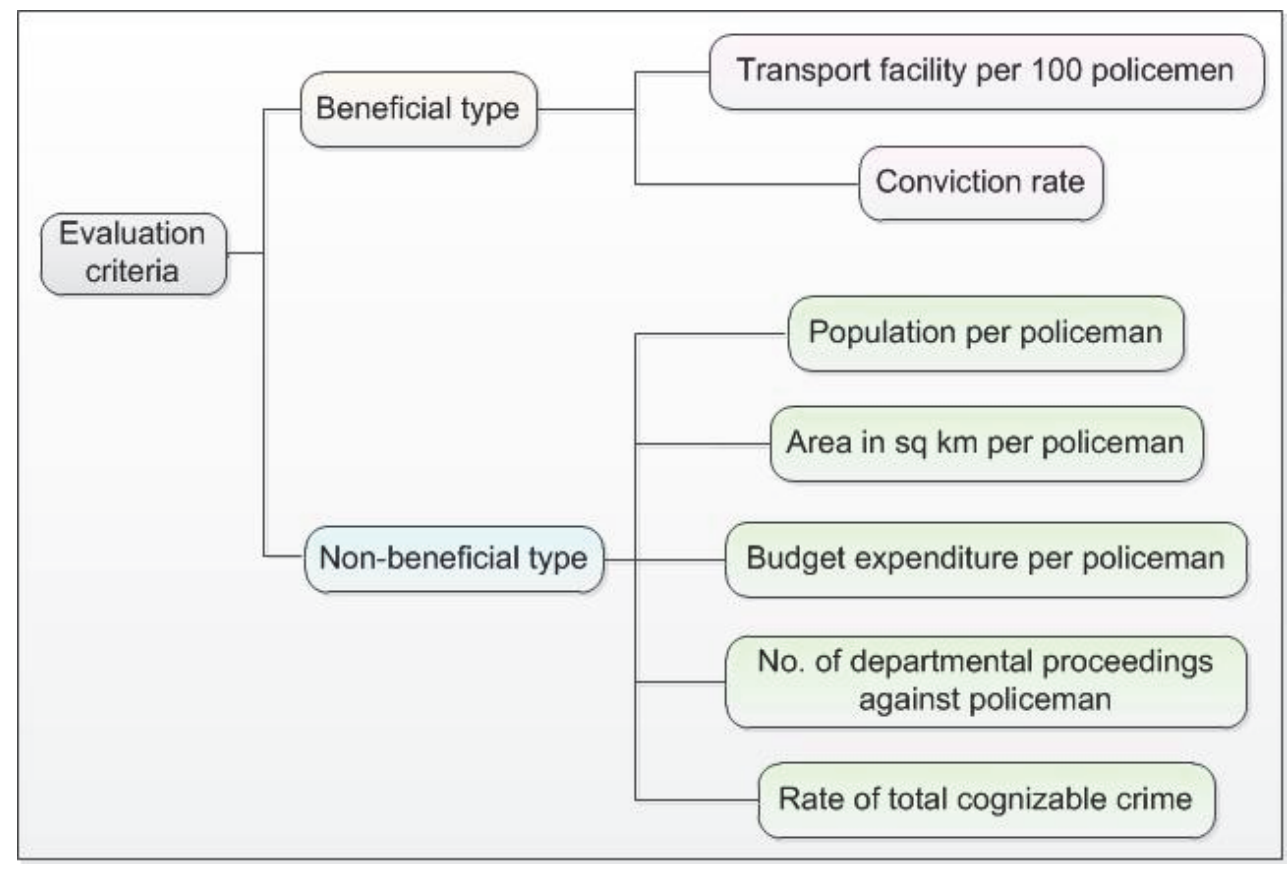

Fig. 1. Classification of criteria for police performance appraisal

Table 1

Seven considered criteria and their weights

\begin{tabular}{clc}
\hline Sl. No. & Criteria & Weight \\
\hline 1. & Population per policeman $\left(\mathrm{C}_{1}\right)$ & 0.1435 \\
2. & Area covered in sq km per policeman $\left(\mathrm{C}_{2}\right)$ & 0.1268 \\
3. & Transport facilities per 100 policemen $\left(\mathrm{C}_{3}\right)$ & 0.1667 \\
4. & Budget expenditure per policeman (in million Rs. $)\left(\mathrm{C}_{4}\right)$ & 0.1950 \\
5. & Departmental proceedings initiated against policeman $\left(\mathrm{C}_{5}\right)$ & 0.0342 \\
6. & Conviction rate $\left(\mathrm{C}_{6}\right)$ & 0.1593 \\
7. & Rate of total cognizable crimes $\left(\mathrm{C}_{7}\right)$ & 0.1745 \\
\hline
\end{tabular}


Population per policeman criterion is of prime importance which determines the number of people guarded by a single policeman. Abysmally, low police to population ratio in India as compared to many other countries may be the cause behind increasing rapes, murders, robberies, and even terrorist and Maoist activities in this country. As on $1^{\text {st }}$ January, 2013, India has about 136.42 police per 100,000 people which is much below the UN peacetime recommendation of 222 police per 100,000 people (i.e. 450 people per policeman). Hence, to ensure safety of the Indian citizens, it is necessary to increase the strength of police forces as the number of policemen has a direct correlation to deter against crime. The area in Sq km per policeman provides a lucid picture of the magnitude of area watched over by a single policeman. Experts often argue that more boots on the ground and greater visibility of police are the greatest deterrents not only against street crimes, such as rape, robbery and murder, but also against terrorist attacks. The transport facility (mobility) per 100 policemen is considered as another important criterion. The mobility is measured in terms of the ability of the entire strength of a police unit to move instantly to the crime spot. Police mobility is directly linked to its performance. Quick response in real time, during law and order situations, significantly helps to preserve the precious lives of people, and protect public and private properties besides being a reliable indicator of police performance. The vehicles needed to provide mobility to the police force are of four types, i.e. heavy vehicles (buses/trucks and troop carriers), medium vehicles (vans), light vehicles (jeeps/cars) and two wheelers. The next considered criterion is the annual budget expenditure per policeman (in million rupees). The expenditure is primarily made on police training, police housing and allocating modernization grants to state police forces. The modernization grants to state police forces, allocated under the Modernization of State Police Forces Scheme of the Ministry of Home Affairs, are especially meant to upgrade the infrastructure of the state police forces in order to improve their capabilities to meet the emerging challenges of internal security in the form of terrorism, extremism, Naxalism etc. besides improving efficiency and effectiveness of police in general. The conviction rate is the percentage of cases convicted as calculated with respect to the total number of cases tried and disposed of. It is an indicator of inadequacies in the criminal justice system in general, and investigation and prosecution in particular. In order to win faith of the citizens in the criminal justice system, all its wings should contribute their efforts to improve the conviction rate. Slow disposal of exhibits has a whiplash effect on the entire chain of investigation, trial and conviction of criminal cases. It also hampers and slows down the investigation process. The total number of departmental proceedings initiated against policeman also plays a pivotal role in providing a clear picture on the fidelity of policeman in a given region. According to the set conduct rules, every police officer must at all times maintain absolute integrity, devotion to duty and do nothing which is unbecoming for a police officer. Every member of the police force should regard himself as a servant and guardian of the general public and treat all lawabiding citizens, irrespective of their social position, with unfailing patience, courtesy and tact. The rate of total cognizable crimes is the last considered criterion in this evaluation process. Cognizable crime is defined as one in which a police officer can arrest an accused without warrant. The police force has a direct responsibility to take immediate action on receipt of a complaint in such crimes by taking steps, like visit to the scene of crime, investigate the facts, apprehend the offender and produce him before a court of law having jurisdiction over the matter. The cognizable crime rate is defined as the total number of crimes per 100,000 of population in a state/UT. It is universally considered as a reliable indicator since it balances the effect of growth in population. The weights of all the seven criteria are now determined using Shannon's entropy method (Rao, 2007), as provided in Table 1. For this police performance evaluation problem, the quantitative data is displayed in the form of a decision matrix in Table 2. The data is accumulated from the Bureau of Police Research and Development website (http://bprd.nic.in/showfile.asp?lid=1216). The data encompasses all the 28 Indian states and 7 UTs. Telengana is not considered here as a separate state since it did not receive its statehood in 2013, the year to which the latest available report dates back. For similar reason, Delhi is considered as an UT and not as a state. This decision matrix is first normalized employing Eq. (5) or (6) and then weighted normalized by multiplying the normalized decision matrix with the corresponding criteria weights. The weighted normalized decision matrix is exhibited in Table 3. 
Table 2

Decision matrix for the police performance appraisal problem

\begin{tabular}{|c|c|c|c|c|c|c|c|c|}
\hline Sl. No. & State/UT & $\mathrm{C}_{1}$ & $\mathrm{C}_{2}$ & $\mathrm{C}_{3}$ & $\mathrm{C}_{4}$ & $\mathrm{C}_{5}$ & $\mathrm{C}_{6}$ & $\mathrm{C}_{7}$ \\
\hline & Ontimal value $\left(\mathrm{A}_{0}\right)$ & 95 & 0.02 & 31,37 & 0.2345 & 0.0001 & 89.50 & 47.70 \\
\hline 1. & Andhra Pradesh $\left(\mathrm{A}_{1}\right)$ & 886 & 2.84 & 10.28 & 0.3449 & 0.0451 & 29.7 & 224.50 \\
\hline 2. & Arunachal Pradesh $\left(\mathrm{A}_{2}\right)$ & 114 & 7.57 & 8.5 & 0.3355 & 0.0105 & 40.5 & 192.10 \\
\hline 3. & $\operatorname{Assam}\left(\mathrm{A}_{3}\right)$ & 563 & 1.42 & 9.1 & 0.2707 & 0.0060 & 10.6 & 250.00 \\
\hline 4. & $\operatorname{Bihar}\left(\mathrm{A}_{4}\right)$ & 1453 & 1.37 & 8.23 & 0.4439 & 0.0002 & 15.9 & 147.40 \\
\hline 5. & Chhattisgarh $\left(\mathrm{A}_{5}\right)$ & 542 & 2.96 & 7.94 & 0.3496 & 0.0068 & 46 & 221.10 \\
\hline 6. & $\operatorname{Goa}\left(A_{6}\right)$ & 347 & 0.7 & 10.58 & 0.4597 & 0.0094 & 22 & 196.70 \\
\hline 7. & Gujarat $\left(\mathrm{A}_{7}\right)$ & 884 & 2.87 & 13.59 & 0.2567 & 0.0211 & 35.5 & 216.60 \\
\hline 8. & Haryana $\left(\mathrm{A}_{8}\right)$ & 665 & 1.13 & 10.6 & 0.4693 & 0.0299 & 31.8 & 240.40 \\
\hline 9. & Himachal Pradesh $\left(\mathrm{A}_{9}\right)$ & 481 & 3.88 & 6.22 & 0.4074 & 0.0001 & 22.9 & 182.60 \\
\hline 10. & Jammu \& Kashmir $\left(\mathrm{A}_{10}\right)$ & 165 & 1.4 & 7.25 & 0.3295 & 0.2371 & 37 & 206.50 \\
\hline 11. & Jharkhand $\left(A_{11}\right)$ & 561 & 1.39 & 1.09 & 0.3754 & 0.0437 & 23.2 & 127.80 \\
\hline 12. & Karnataka $\left(\mathrm{A}_{12}\right)$ & 852 & 2.71 & 16.22 & 0.3043 & 0.0057 & 31.5 & 222.50 \\
\hline 13. & Kerala $\left(\mathrm{A}_{13}\right)$ & 702 & 0.78 & 13.04 & 0.3067 & 0.0173 & 65.4 & 455.80 \\
\hline 14. & Madhya Pradesh $\left(\mathrm{A}_{14}\right)$ & 953 & 3.97 & 10.09 & 0.3459 & 0.0206 & 47.7 & 298.80 \\
\hline 15. & Maharashtra $\left(A_{15}\right)$ & 588 & 1.57 & 7.99 & 0.2542 & 0.0023 & 9.4 & 176.70 \\
\hline 16. & $\operatorname{Manipur}\left(\mathrm{A}_{16}\right)$ & 102 & 0.91 & 8.65 & 0.2345 & 0.0085 & 70 & 150.30 \\
\hline 17. & Meghalaya $\left(\mathrm{A}_{17}\right)$ & 236 & 1.98 & 8.62 & 0.2614 & 0.0043 & 43.3 & 96.10 \\
\hline 18. & $\operatorname{Mizoram}\left(\mathrm{A}_{18}\right)$ & 100 & 2.06 & 6.65 & 0.3043 & 0.0174 & 89.5 & 173.10 \\
\hline 19. & Nagaland $\left(\mathrm{A}_{19}\right)$ & 95 & 0.68 & 5.74 & 0.2638 & 0.0014 & 85.8 & 47.70 \\
\hline 20. & Odisha $\left(\mathrm{A}_{20}\right)$ & 911 & 3.43 & 11.32 & 0.3756 & 0.0176 & 11 & 164.80 \\
\hline 21. & Punjab $\left(A_{21}\right)$ & 453 & 0.81 & 7.29 & 0.4709 & 0.0001 & 37.5 & 127.40 \\
\hline 22. & Rajasthan $\left(\mathrm{A}_{22}\right)$ & 802 & 3.95 & 6.51 & 0.2857 & 0.0408 & 61.3 & 246.90 \\
\hline 23. & $\operatorname{Sikkim}\left(\mathrm{A}_{23}\right)$ & 158 & 1.79 & 11.72 & 0.4231 & 0.0104 & 38.7 & 84.90 \\
\hline 24. & Tamil Nadu $\left(\mathrm{A}_{24}\right)$ & 721 & 1.38 & 15.34 & 0.3955 & 0.0496 & 56.5 & 294.80 \\
\hline 25. & Tripura $\left(\mathrm{A}_{25}\right)$ & 155 & 0.44 & 7.15 & 0.2774 & 0.0029 & 14.9 & 170.60 \\
\hline 26. & Uttar Pradesh $\left(\mathrm{A}_{26}\right)$ & 1234 & 1.44 & 7.85 & 0.4265 & 0.0475 & 52.6 & 96.40 \\
\hline 27. & Uttarakhand $\left(\mathrm{A}_{27}\right)$ & 570 & 3 & 7.2 & 0.3574 & 0.0218 & 76.3 & 87.70 \\
\hline 28. & West Bengal $\left(\mathrm{A}_{28}\right)$ & 1286 & 1.26 & 9.48 & 0.3629 & 0.0113 & 10.5 & 178.20 \\
\hline 29. & Andaman \& Nicobar Islands $\left(\mathrm{A}_{29}\right)$ & 137 & 2.19 & 11.88 & 0.3979 & 0.0027 & 54.2 & 133.40 \\
\hline 30. & Chandigarh $\left(\mathrm{A}_{30}\right)$ & 218 & 0.02 & 6.8 & 0.3076 & 0.0216 & 50.5 & 235.40 \\
\hline 31. & Dadra \& Nagar Haveli $\left(\mathrm{A}_{31}\right)$ & 1402 & 1.81 & 31.37 & 0.4468 & 0.0037 & 10 & 84.60 \\
\hline 32. & Daman \& Diu $\left(\mathrm{A}_{32}\right)$ & 1175 & 0.46 & 22.76 & 0.3207 & 0.0001 & 13.8 & 83.90 \\
\hline 33. & Delhi $\left(\mathrm{A}_{33}\right)$ & 256 & 0.02 & 8.26 & 0.4693 & 0.0111 & 52.4 & 283.30 \\
\hline 34. & Lakshadweep $\left(\mathrm{A}_{34}\right)$ & 279 & 0.12 & 23.91 & 0.6007 & 0.0072 & 36.9 & 77.90 \\
\hline 35. & Puducherry $\left(\mathrm{A}_{35}\right)$ & 564 & 0.18 & 17.29 & 0.3548 & 0.0121 & 79.9 & 291.00 \\
\hline
\end{tabular}

Now applying Eqs. (7-8), the values of optimality function $\left(S_{i}\right)$ and degree of alternative utility $\left(K_{i}\right)$ are respectively computed for each Indian state/UT, and henceforth are given in Table 4. Finally, the values of $K_{i}$ are employed to rank all the Indian states/UTs with respect to their performance in police activities. The rankings of the Indian states/UTs in police performance are exhibited in Fig. 2.

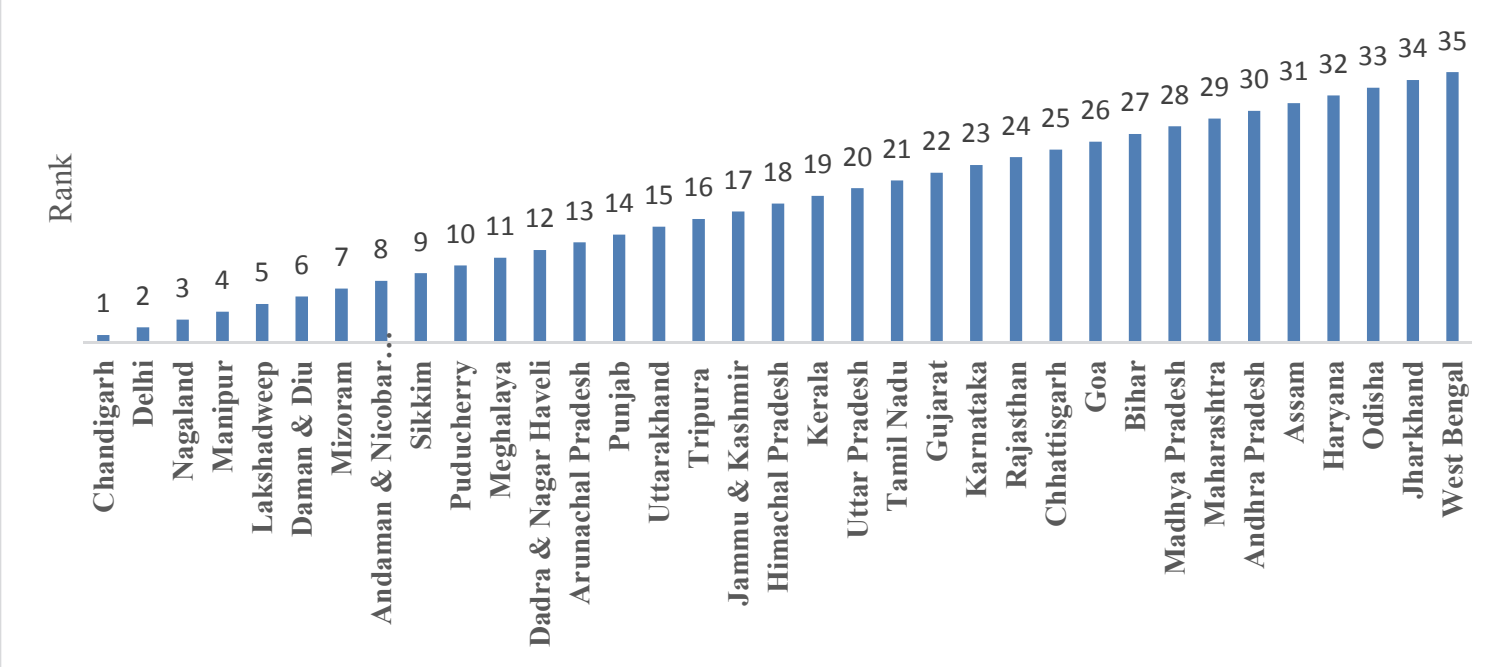

Fig. 2 Rankings of Indian states/UTs with respect to police performance

As illustrated in Fig. 2, the police performance in Chandigarh is the best amongst all others nationwide, whilst the performance of police in the state of West Bengal is the worst. A further analysis of this figure leads to certain interesting derivations. It is observed that the police forces in Indian UTs, in general, perform quite well as compared to their counterparts in other states. In order to analyse the 
derived observations in details, a zonal analysis of the police performance is carried out while classifying the entire gamut of Indian states/UTs under seven broad divisions/zones, according to the predefined administrative sub-categorizations.

Table 3

Weighted normalized decision matrix

\begin{tabular}{|c|c|c|c|c|c|c|c|}
\hline Criteria & $\mathrm{C}_{1}$ & $\mathrm{C}_{2}$ & $\mathrm{C}_{3}$ & $\mathrm{C}_{4}$ & $\mathrm{C}_{5}$ & $\mathrm{C}_{6}$ & $\mathrm{C}_{7}$ \\
\hline Criteria type & Min & Min & Max & Min & Min & Max & Min \\
\hline Weight & 0.1435 & 0.1268 & 0.1667 & 0.1950 & 0.0342 & 0.1593 & 0.1745 \\
\hline $\mathrm{A}_{0}$ & 0.01210 & 0.03391 & 0.01282 & 0.00783 & 0.00701 & 0.00948 & 0.01414 \\
\hline $\mathrm{A}_{1}$ & 0.00130 & 0.00024 & 0.00420 & 0.00532 & 0.00002 & 0.00315 & 0.00300 \\
\hline $\mathrm{A}_{2}$ & 0.01008 & 0.00009 & 0.00347 & 0.00547 & 0.00007 & 0.00429 & 0.00351 \\
\hline $\mathrm{A}_{3}$ & 0.00204 & 0.00048 & 0.00372 & 0.00678 & 0.00012 & 0.00112 & 0.00270 \\
\hline $\mathrm{A}_{4}$ & 0.00079 & 0.00050 & 0.00336 & 0.00413 & 0.00321 & 0.00168 & 0.00457 \\
\hline $\mathrm{A}_{5}$ & 0.00212 & 0.00023 & 0.00325 & 0.00525 & 0.00010 & 0.00487 & 0.00305 \\
\hline $\mathrm{A}_{6}$ & 0.00331 & 0.00097 & 0.00432 & 0.00399 & 0.00007 & 0.00233 & 0.00343 \\
\hline $\mathrm{A}_{7}$ & 0.00130 & 0.00024 & 0.00555 & 0.00715 & 0.00003 & 0.00376 & 0.00311 \\
\hline $\mathrm{A}_{8}$ & 0.00173 & 0.00060 & 0.00433 & 0.00391 & 0.00002 & 0.00337 & 0.00280 \\
\hline $\mathrm{A}_{9}$ & 0.00239 & 0.00017 & 0.00254 & 0.00450 & 0.00701 & 0.00243 & 0.00369 \\
\hline $\mathrm{A}_{10}$ & 0.00696 & 0.00048 & 0.00296 & 0.00557 & 0.00000 & 0.00392 & 0.00327 \\
\hline $\mathrm{A}_{11}$ & 0.00205 & 0.00049 & 0.00045 & 0.00489 & 0.00002 & 0.00246 & 0.00528 \\
\hline $\mathrm{A}_{12}$ & 0.00135 & 0.00025 & 0.00663 & 0.00603 & 0.00012 & 0.00334 & 0.00303 \\
\hline $\mathrm{A}_{13}$ & 0.00164 & 0.00087 & 0.00533 & 0.00598 & 0.00004 & 0.00693 & 0.00148 \\
\hline $\mathrm{A}_{14}$ & 0.00121 & 0.00017 & 0.00412 & 0.00531 & 0.00003 & 0.00505 & 0.00226 \\
\hline $\mathrm{A}_{15}$ & 0.00195 & 0.00043 & 0.00327 & 0.00722 & 0.00030 & 0.00100 & 0.00382 \\
\hline $\mathrm{A}_{16}$ & 0.01127 & 0.00075 & 0.00354 & 0.00783 & 0.00008 & 0.00741 & 0.00449 \\
\hline $\mathrm{A}_{17}$ & 0.00487 & 0.00034 & 0.00352 & 0.00702 & 0.00016 & 0.00459 & 0.00702 \\
\hline $\mathrm{A}_{18}$ & 0.01149 & 0.00033 & 0.00272 & 0.00603 & 0.00004 & 0.00948 & 0.00390 \\
\hline $\mathrm{A}_{19}$ & 0.01210 & 0.00100 & 0.00235 & 0.00696 & 0.00050 & 0.00909 & 0.01414 \\
\hline $\mathrm{A}_{20}$ & 0.00126 & 0.00020 & 0.00463 & 0.00489 & 0.00004 & 0.00116 & 0.00409 \\
\hline $\mathrm{A}_{21}$ & 0.00254 & 0.00084 & 0.00298 & 0.00390 & 0.00701 & 0.00397 & 0.00529 \\
\hline $\mathrm{A}_{22}$ & 0.00143 & 0.00017 & 0.00266 & 0.00642 & 0.00002 & 0.00649 & 0.00273 \\
\hline $\mathrm{A}_{23}$ & 0.00727 & 0.00038 & 0.00479 & 0.00434 & 0.00007 & 0.00410 & 0.00794 \\
\hline $\mathrm{A}_{24}$ & 0.00159 & 0.00049 & 0.00627 & 0.00464 & 0.00001 & 0.00598 & 0.00229 \\
\hline $\mathrm{A}_{25}$ & 0.00741 & 0.00154 & 0.00292 & 0.00662 & 0.00024 & 0.00158 & 0.00395 \\
\hline $\mathrm{A}_{26}$ & 0.00093 & 0.00047 & 0.00321 & 0.00430 & 0.00001 & 0.00557 & 0.00699 \\
\hline $\mathrm{A}_{27}$ & 0.00202 & 0.00023 & 0.00294 & 0.00514 & 0.00003 & 0.00808 & 0.00769 \\
\hline $\mathrm{A}_{28}$ & 0.00089 & 0.00054 & 0.00387 & 0.00506 & 0.00006 & 0.00111 & 0.00378 \\
\hline $\mathrm{A}_{29}$ & 0.00839 & 0.00031 & 0.00486 & 0.00461 & 0.00026 & 0.00574 & 0.00505 \\
\hline $\mathrm{A}_{30}$ & 0.00527 & 0.03391 & 0.00278 & 0.00597 & 0.00003 & 0.00535 & 0.00286 \\
\hline $\mathrm{A}_{31}$ & 0.00082 & 0.00037 & 0.01282 & 0.00411 & 0.00019 & 0.00106 & 0.00797 \\
\hline $\mathrm{A}_{32}$ & 0.00098 & 0.00147 & 0.00930 & 0.00572 & 0.00701 & 0.00146 & 0.00804 \\
\hline $\mathrm{A}_{33}$ & 0.00449 & 0.03391 & 0.00338 & 0.00391 & 0.00006 & 0.00555 & 0.00238 \\
\hline $\mathrm{A}_{34}$ & 0.00412 & 0.00565 & 0.00977 & 0.00306 & 0.00010 & 0.00391 & 0.00866 \\
\hline $\mathrm{A}_{35}$ & 0.00204 & 0.00377 & 0.00707 & 0.00517 & 0.00006 & 0.00846 & 0.00232 \\
\hline
\end{tabular}

Table 4

Rankings of the Indian states/UTs

\begin{tabular}{|c|c|c|c|c|c|c|c|}
\hline State/UT & $S_{i}$ & $K_{i}$ & Rank & State/UT & $S_{i}$ & $K_{i}$ & Rank \\
\hline Andhra Pradesh $\left(\mathrm{A}_{1}\right)$ & 0.01722 & 0.17703 & 30 & Nagaland $\left(\mathrm{A}_{19}\right)$ & 0.04612 & 0.47404 & 3 \\
\hline Arunachal Pradesh $\left(\mathrm{A}_{2}\right)$ & 0.02698 & 0.27732 & 13 & Odisha $\left(\mathrm{A}_{20}\right)$ & 0.01627 & 0.16722 & 33 \\
\hline $\operatorname{Assam}\left(\mathrm{A}_{3}\right)$ & 0.01695 & 0.17427 & 31 & Punjab $\left(A_{21}\right)$ & 0.02653 & 0.27268 & 14 \\
\hline Bihar $\left(\mathrm{A}_{4}\right)$ & 0.01825 & 0.18762 & 27 & Rajasthan ( $\left.\mathrm{A}_{22}\right)$ & 0.01993 & 0.20486 & 24 \\
\hline Chhattisgarh $\left(\mathrm{A}_{5}\right)$ & 0.01887 & 0.19395 & 25 & Sikkim $\left(\mathrm{A}_{23}\right)$ & 0.02889 & 0.29693 & 9 \\
\hline Goa $\left(\mathrm{A}_{6}\right)$ & 0.01843 & 0.18944 & 26 & Tamil Nadu $\left(\mathrm{A}_{24}\right)$ & 0.02128 & 0.21874 & 21 \\
\hline Gujarat $\left(\mathrm{A}_{7}\right)$ & 0.02114 & 0.21735 & 22 & Tripura $\left(\mathrm{A}_{25}\right)$ & 0.02427 & 0.24943 & 16 \\
\hline Haryana $\left(\mathrm{A}_{8}\right)$ & 0.01677 & 0.17235 & 32 & Uttar Pradesh $\left(\mathrm{A}_{26}\right)$ & 0.02149 & 0.22092 & 20 \\
\hline Himachal Pradesh $\left(\mathrm{A}_{9}\right)$ & 0.02274 & 0.23377 & 18 & Uttarakhand $\left(\mathrm{A}_{27}\right)$ & 0.02612 & 0.2685 & 15 \\
\hline Jammu \& Kashmir ( $\left.\mathrm{A}_{10}\right)$ & 0.02317 & 0.23814 & 17 & West Bengal ( $\left.\mathrm{A}_{28}\right)$ & 0.01532 & 0.15749 & 35 \\
\hline Jharkhand $\left(\mathrm{A}_{11}\right)$ & 0.01562 & 0.16055 & 34 & Andaman \&Nicobar Islands ( $\left.\mathrm{A}_{29}\right)$ & 0.02922 & 0.30039 & 8 \\
\hline Karnataka $\left(\mathrm{A}_{12}\right)$ & 0.02075 & 0.21326 & 23 & Chandigarh $\left(\mathrm{A}_{30}\right)$ & 0.05618 & 0.57743 & 1 \\
\hline Kerala $\left(\mathrm{A}_{13}\right)$ & 0.02226 & 0.22886 & 19 & Dadra \&Nagar Haveli $\left(\mathrm{A}_{31}\right)$ & 0.02734 & 0.28104 & 12 \\
\hline Madhya Pradesh $\left(\mathrm{A}_{14}\right)$ & 0.01815 & 0.18654 & 28 & Daman \& Diu $\left(\mathrm{A}_{32}\right)$ & 0.03399 & 0.34937 & 6 \\
\hline Maharashtra $\left(\mathrm{A}_{15}\right)$ & 0.01798 & 0.18485 & 29 & Delhi $\left(\mathrm{A}_{33}\right)$ & 0.05368 & 0.55181 & 2 \\
\hline Manipur $\left(\mathrm{A}_{16}\right)$ & 0.03535 & 0.36341 & 4 & Lakshadweep $\left(\mathrm{A}_{34}\right)$ & 0.03526 & 0.36242 & 5 \\
\hline Meghalaya $\left(\mathrm{A}_{17}\right)$ & 0.02752 & 0.28287 & 11 & Puducherry (A35) & 0.02888 & 0.29687 & 10 \\
\hline Mizoram (A18) & 0.03398 & 0.34931 & 7 & & & & \\
\hline
\end{tabular}



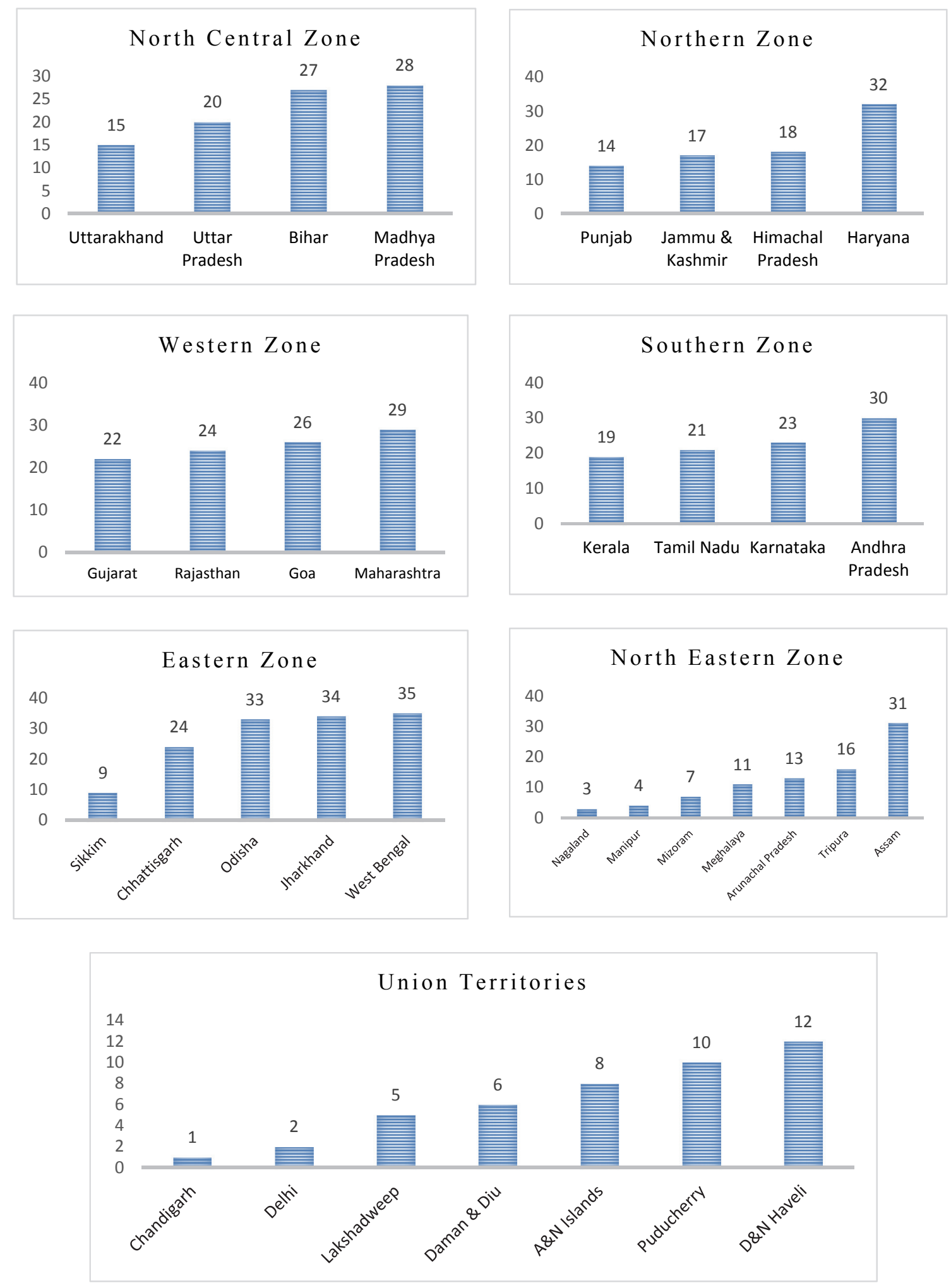

Fig. 3. Ranks of Indian States/UTs according to zonal classification

Fig. 3 shows the ranks of Indian states/UTs based on the above-mentioned zonal classification. It can be inferred that all the UTs perform extremely well. Interestingly, six out of the seven UTs are amongst the top ten best performing states/UTs. It can also be concluded that except Sikkim, all other states in 
the Eastern zone, i.e. Chhattisgarh, Jharkhand, West Bengal and Odisha exhibit extremely poor performance. Basically, West Bengal, Jharkhand and Odisha occupy the last three positions with respect to their police performance. The states in the Northern zone display moderate police performance with Haryana being the only exception having unsatisfactory performance. The performance of police in the Western, Southern and North Central zones can be considered as vacillating between moderate and poor. All the states belonging to North Eastern zone exhibit praiseworthy police performance, with the exception of Assam wherein the police forces have displayed rather poor performance. Another important conclusion can be drawn if one attempts to correlate the ranks of Indian states/UTs against their geographical areas. It is observed that the police performance in smaller states, like Nagaland, Manipur, Mizoram, Meghalaya, Tripura, Sikkim and the UTs is extremely satisfactory. The worse ranks of the severely affected Naxalite states, i.e. Chhattisgarh, Jharkhand, Bihar, Andhra Pradesh and Odisha provide a clear indication of immediate attention which is necessary to improve police performance and thereby, curb such insurgent crimes.

The best rank achieved by the police forces of Chandigarh exactly corroborates with the observations of a recently published report in www.chandigarhpolice.nic.in. According to that report, the performance of police forces in Chandigarh has been appreciated at various forums during the year 2014 and got appreciation letters from the Honourable Chief Justice of Punjab and Haryana High Court, which is a rare honour for its police force. During the year 2014, Chandigarh police has to face the challenge of conducting Parliament Elections, which they have successfully completed. Thereafter, during the last quarter of 2014, they have dealt in a most successful and professional way with the threat of siege of Chandigarh by the followers of Baba Ram Pal. The excellent performance of Chandigarh police, as obtained using ARAS method, is substantiated by the fact that it is the first ever state/UT in India wherein all the police stations are awarded the International Organization for Standardization (ISO) 9001:2000 certificate (http://articles.economictimes.indiatimes.com/2008-0524/news/27691879_1_iso-certification-police-stations-quality-service). Modi International, the designated agency for certification, carried out an extensive survey and conducted a thorough audit of all the operations before granting the ISO certification in 2009. All 11 police stations in Chandigarh boast of having world-class infrastructure, which contributes a great deal to their abilities and performance. Closed circuit television cameras are installed in every police station so that the topranked officials can constantly monitor the situation, helping to promote and develop healthy operational traits amongst the police personnel. Citizen satisfaction is another area where Chandigarh police performs brilliantly. They have a well-established system for maintaining a healthy police-public interaction and the general public's perception about Chandigarh police is very good.

There are several reasons for West Bengal attaining the worst rank in this police performance appraisal problem. Nearly $66 \%$ of the people in West Bengal think that the behaviour of the police towards them is unsatisfying (Ghosh, 2007). Thus, in general public's perception, the present state of police accountability is poor. According to Human Rights Commission, police at times do use third degree methods and also illegally confine people at the police stations. In fact, the internal SWOT (strengths, weaknesses, opportunities and threats) analysis carried out by the West Bengal Police (WBP) department (http://policewb.gov.in/wbp/misc/2020/internal analysis.pdf) explicitly mentions acute manpower shortage, excessive politicization, inadequate police budget, high physical and mental stress sustained by the field officers, poor police image and corruption as the main weaknesses that are currently plaguing their performance. To improve the present situation, immediate action is necessary. The first priority is to ensure strict enforcement of law in every situation. Actions, like non-registration of crimes and misrepresentation of facts should be met with zero tolerance. Investments should be made to upgrade the current equipment at the state forensic laboratories, lack of which is currently hindering the performance of WBP. Apart from Kolkata Police, which is an established Police Commissionerate (PC) since 1856, WBP currently has four PCs located in Howrah Town, Barrackpore, Bidhannnagar and Asansol-Durgapur. However, PCs with magisterial powers of law and order vested in the Commissioner of Police are also necessary in upcoming urban areas, like Siliguri, Haldia, Serampore 
and Kharagpur since these areas are witnessing a huge influx of population. In order to ensure proper and unbiased functioning of the police force, political overtones in police activities must be banned. Infrastructure-wise also, the WBP falls far behind as compared to the other states. Some police stations in West Bengal lack even the basic amenities, like electricity, water and sanitation, sufficient provisions for which, must be made. The WBP vehicles must be equipped with GPS tracking devices in order to improve efficiency, reduce response time and prevent misuse.

As depicted in Fig. 2, majority of the poor ranks are attained by the severely affected Naxalite states and it is firmly in tune with the article published in the Indian Express on $25^{\text {th }}$ April, 2015. Despite increase in the boots on the ground, the Maoist-dominated areas that the forces are supposed to recapture remain elusive. Even though the Central Government has spent huge money towards security related expenditure and set up counter-insurgency and anti-terrorist training institutions in the affected states, the effectiveness of police forces has not been increased to the satisfactory levels.

\section{Conclusions}

In this paper, an attempt is made to evaluate the performance of state police forces in India using ARAS method based on seven entirely uncorrelated criteria. In order to avoid subjective judgments, Shannon's entropy method is employed for computing the criteria weights. It is observed from the analysis that the police performance in Chandigarh is the best, while the state of West Bengal has the worst performance regarding its police activities. An analysis of the derived results reveals that the police forces in Indian UTs perform quite well as compared to their counterparts in other states. The main focus of this police performance appraisal problem lies in identifying those poor or under-performing Indian states/UTs so that necessary corrective actions can be formulated in order to improve their performance, thereby solidifying the presence of law and order in the country. However, there is also enough scope for carrying out future research work in this area while taking into consideration a variety of other criteria, like difference in remuneration of policemen in individual state/UT, variation in the number of working hours per day per policeman in different states/UTs, responsiveness of the police indicated by the average time required to reach the crime scene, total number of vacancies in individual police department in each state/UT for evaluating the performance of Indian police forces. Furthermore, the police performance can also be thoroughly investigated in specific areas, like states bordering neighbouring countries, industrially oriented socio-economic zones, areas with high forest coverage, areas located at high altitudes above the sea level and so on.

\section{Acknowledgement}

The authors would like to thank the anonymous referees for constructive comments on earlier version of this paper.

\section{References}

Diez-Ticio, A., \& Mancebon, M.J. (2002). The efficiency of the Spanish police service: An application of the multi-activity DEA model. Applied Economics, 34(3), 351-362.

Drake, L., \& Simper, R. (2003). The measurement of English and Welsh police force efficiency: A comparison of distance function models. European Journal of Operational Research, 147(1), 165186.

Drake, H.M., \& Simper, R. (2005). The measurement of police force efficiency: An assessment of UK Home Office policy. Contemporary Economic Policy, 23(4), 465-482.

García-Sánchez, I.M. (2007). Evaluating the effectiveness of the Spanish police force through data envelopment analysis. European Journal of Law and Economics, 23(1), 43-57. 
Ghosh, G. (2007). Police accountability: At the cutting edge level. A.P.H. Publishing Corporation, India.

Gorman, M. F., \& Ruggiero, J. (2008). Evaluating US state police performance using data envelopment analysis. International Journal of Production Economics, 113(2), 1031-1037.

Kutut, V., Zavadskas, E.K., \& Lazauskas, M. (2013). Assessment of priority options for preservation of historic city centre buildings using MCDM (ARAS). Procedia Engineering, 57, 657-661.

Moore, M.H., \& Braga, A.A. (2003). Measuring and improving police performance: The lessons of Compstat and its progeny. Policing: An International Journal of Police Strategies \& Management, 26(3), 439-453.

Rao, R.V. (2007). Decision making in the manufacturing environment using graph theory and fuzzy multiple attribute decision making methods. London : Springer-Verlag.

Sadi-Nezhad, S., \& Damghani, K.K. (2010). Application of a fuzzy TOPSIS method base on modified preference ratio and fuzzy distance measurement in assessment of traffic police canter's performance. Applied Soft Computing, 10(4), 1028-1039.

Stanujkic, D., Đorđević, B., \& Đorđević,M. (2013). Comparative analysis of some prominent MCDM methods: A case of ranking Serbian banks. Serbian Journal of Management, 8(2), 213-241.

Sun, S. (2002). Measuring the relative efficiency of police precincts using data envelopment analysis. Socio-Economic Planning Sciences, 36(1), 51-71.

Turskis, Z., \& Zavadskas, E.K. (2010). A novel method for multiple criteria analysis: Grey additive ratio assessment (ARAS-G) method. Informatica, 21(4), 597-610.

Verma, A., \& Gavirneni, S. (2006). Measuring police efficiency in India: An application of data envelopment analysis. Policing: An International Journal of Police Strategies \& Management, 29(1), 125-145.

Wu, T.H., Chen, M.S., \& Yeh, J.Y. (2010). Measuring the performance of police forces in Taiwan using data envelopment analysis. Evaluation and Program Planning, 33(3), 246-254.

Zavadskas, E.K. \& Turskis, Z. (2010). A new additive ratio assessment (ARAS) method in multicriteria decision-making. Technological and Economic Development of Economy, 16(2), 159-172.

Zavadskas, E.K., Turskis, Z., \& Vilutiene, T. (2010). Multiple criteria analysis of foundation installment alternatives by applying additive ratio assessment (ARAS) method. Archives of Civil and Mechanical Engineering, 10(3), 123-141.

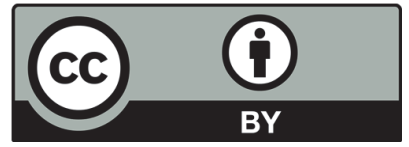

(C) 2016 by the authors; licensee Growing Science, Canada. This is an open access article distributed under the terms and conditions of the Creative Commons Attribution (CC-BY) license (http://creativecommons.org/licenses/by/4.0/). 